\title{
A Blood-brain Barrier Permeable Derivative of 5-Fluorouracil: Preparation, Intracellular Localization, and Mouse Tissue Distribution
}

\author{
Jungkyun Im, Goutam Biswas, Wanil Kim, ${ }^{\dagger}$ Kyong-Tai Kim, ${ }^{\dagger}$ and Sung-Kee Chung ${ }^{*}$ \\ Department of Chemistry, Pohang University of Science and Technology, Pohang 790-784, Korea \\ ${ }^{*}$ E-mail: skchung@postech.ac.kr \\ ${ }^{\dagger}$ Department of Life Science, Pohang University of Science and Technology, Pohang 790-784, Korea \\ Received December 7, 2010, Accepted January 5, 2011
}

\begin{abstract}
5-Fluorouracil (5-FU), an anticancer agent was covalently attached to the recently developed sorbitol-based G8 transporter, and the conjugate (7) with FITC was found to have an affinity toward mitochondria and to readily cross $\mathrm{BBB}$ to gain an entry into mouse brain. Measured by $\mathrm{IC}_{50}$, the conjugate $(9)$ without the fluorophore showed enhanced cytotoxic activity toward two types of multidrug-resistant cell lines. These results strongly suggest that the sorbitol-based G8 transporter can be utilized as a good CNS delivery vector.
\end{abstract}

Key Words : Blood-brain barrier, G8 molecular transporter, CNS delivery, anti-cancer agent

\section{Introduction}

Antimetabolites are the agents which have molecular structures similar to normal cellular metabolites. 5-Fluorouracil (5-FU, Figure 1a) was the first antimetabolite approved for solid tumors such as breast, colorectal, and head and neck cancers, and has been in clinical use for more than 45 years. ${ }^{1}$ Uridine is involved in the biosynthesis of thymidine which is one of DNA building blocks, and thus 5FU or 5-FU metabolites can interfere with the biosynthetic processes of thymidine and impart significant toxicity to the rapidly dividing cells, such as cancer cells. 5-FU can be taken up by a cell via the facilitated transport mechanism available for uracil, and several intercellular enzymes will convert 5-FU to various metabolites. ${ }^{2}$ Among them, fluorodeoxyuridine monophosphate (FdUMP), the competitive inhibitor with a structure similar to the normal substrate, (a)<smiles>O=c1[nH]cc(F)c(=O)[nH]1</smiles>

(b)<smiles>Cc1c[nH]c(=O)[nH]c1=O</smiles>

(c)<smiles>O=c1cc[nH]c(=O)[nH]1</smiles>

Figure 1. (a) 5-FU, (b) thymine, (c) uracil

deoxyuridine monophosphate (dUMP), can inhibit the enzymatic event of thymidylate synthase (TS) which is essential for the thymidine biosynthesis. Therefore, the activity of TS is reduced, causing the imbalance of deoxynucleotides and the increased levels of dUMP, dUDP (deoxyuridine diphosphate) and dUTP (deoxyuridine triphosphate) in the cell. Eventually, incorporation of dUTP to DNA is increased, followed by DNA damage, cell cycle arrest, and apoptosis. ${ }^{3}$

Although 5-FU is widely used, its pharmacokinetic profile leaves a lot to be desired; it is quickly metabolized with mean half-life of about 16 min; within $3 \mathrm{hr}$, no intact drug can be detected in plasma. Therefore, 5-FU can be admini- stered only by continuous intravenous infusion. ${ }^{1 \mathrm{~b}, 4}$ In order to overcome the poor bioavailability as well as toxicities of $5-\mathrm{FU}$, several orally active pro-drugs of 5-FU such as tegafur, carmofur, doxifluridine, and capecitabine have been developed with improved tumor selectivity, efficacy and safety. ${ }^{1,5}$ Capecitabine (N4-pentyloxycarbony-5-deoxy-5fluorocytidine, Xeloda) is a pro-drug form of 5-FU, and readily absorbed through the intestine. In the target tissues, an intermediary metabolite of capecitabine is converted to 5FU by thymidine phosphorylase (TP), which is found at higher concentration in tumor tissues than normal tissues, accounting for the tumor selectivity of capecitabine. ${ }^{6}$ However, 5-FU or capecitabine is not used for the treatment of brain tumor, primarily because of their inability to cross the blood-brain barrier (BBB) in sufficient concentrations. ${ }^{7}$ Brain tumors represent a heterogeneous group of the central nervous system (CNS) neoplasms of more than 100 different types. Glioblastoma multiforme is the most aggressive type of tumor in CNS. The first line of treatment of glioblastoma is surgery, which is then followed by radiotherapy in parallel with chemotherapy. In general, however, there is a dearth of anti-cancer drugs suitable for the treatment of brain cancer, and the only a BBB-penetrating chemotherapeutic agent is temozolomide, an old alkylating agent. ${ }^{8}$

In various attempts to deliver 5-FU to brain, 5-FU was incorporated into implantable, biodegradable microspheres which could protect the contents and allow its slow release. ${ }^{9}$ Although 5-FU-loaded microspheres were investigated for treatment of brain tumors (glioblastoma) and they appeared to be reasonably efficient for the delivery to brain tumors, the microspheres could be applied to patients only by stereotaxic implantation. ${ }^{9 \mathrm{~b}}$ In a related effort, the transferrincoupled liposome bearing 5-FU was prepared and it showed a 17 -fold increase in the brain uptake of 5-FU. ${ }^{10}$ Recently, we have developed a number of guanidine-rich molecular transporters with high molecular weights and good aqueous solubility, which however readily cross BBB thus displaying 
efficient distributions in mouse brain. ${ }^{11}$ In particular, the G8 (eight guanidine residue containing) molecular transporters built on the sorbitol scaffold was found to show high efficiency in crossing BBB. ${ }^{11 \mathrm{~b}, 11 \mathrm{e}}$ This particular molecular transporter has been successfully utilized in preparing conjugates with anticancer drugs such as doxorubicin and taxol, and these conjugates have shown interesting anticancer activities in the mouse models of glioblastoma. ${ }^{12}$ Herein we wish to report the preparation and efficient delivery into mouse brain of the molecular transporter covalently conjugated with 5-fluorouridine.

\section{Results and Discussion}

It has been reported that the prodrug capecitabine is efficiently metabolized to 5-fluoro-5-deoxyuridine and 5-FU
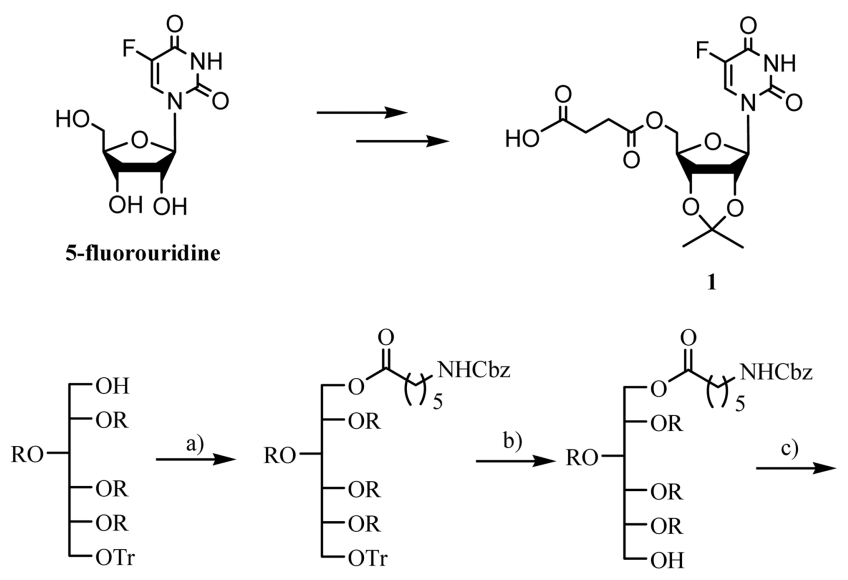

2

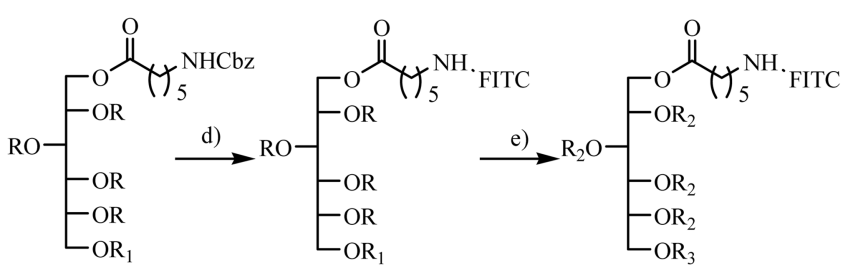

5

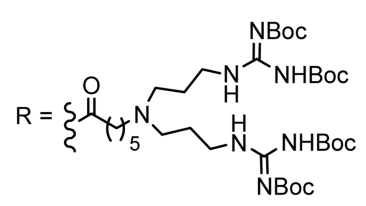

7
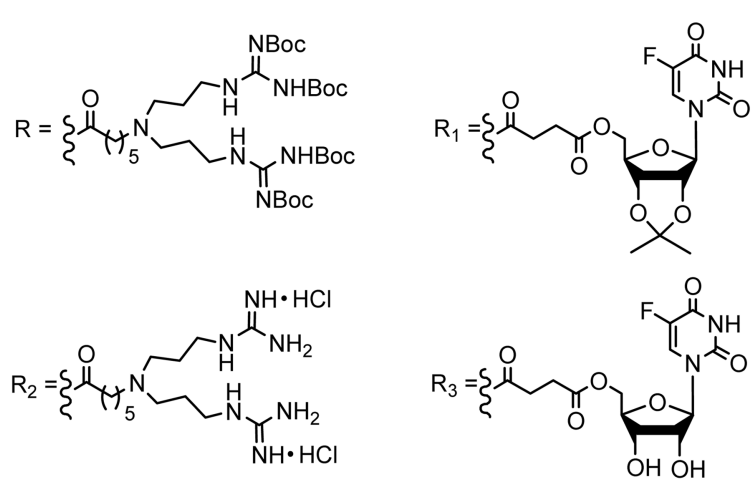

Scheme 1. (a) HOOC- $\left(\mathrm{CH}_{2}\right)_{5}-\mathrm{NHCbz}, \mathrm{EDC}, \mathrm{DMAP}, \mathrm{CH}_{2} \mathrm{Cl}_{2}, \mathrm{rt}, 2$ days, 71\%; (b) flash column $\left(\mathrm{SiO}_{2}\right)$ with hexane-1\% TFA and hexane-1\% Et ${ }_{3} \mathrm{~N}, 73 \%$; (c) 1, EDC, DMAP, DMF, rt, 2 days, 71\%; (d) i) $10 \% \mathrm{Pd} / \mathrm{C}, \mathrm{H}_{2}(50 \mathrm{psi}), \mathrm{MeOH}-\mathrm{CH}_{2} \mathrm{Cl}_{2}$ (9:1), 12 hr, quant., ii) FITC-I, Et ${ }_{3} \mathrm{~N}$, THF, EtOH, rt, 36 hr, 57\%; (e) $\mathrm{HCl}$ (g) in EtOAc, rt, $24 \mathrm{hr}, 72 \%$. in liver and target tumor cells, and then 5-FU is rapidly converted in plasma to FdUMP, and 5-fluorodeoxyuridine trisphosphate (FdUTP). ${ }^{5 a, 6 a}$ In preparing a covalent conjugate of 5-FU to the sorbitol-based G8 transporter, we have decided to attach 5-fluorouridine to the transporter via the succinate ester as a linker. ${ }^{13}$ Such a derivative is expected to be cleaved in the body to 5 -FU by esterase ${ }^{13 b}$ and thymidine phosphorylase. ${ }^{6}$ It is further envisioned that the pharmacokinetic properties of the conjugate may be refined by changing the linker structure, if needed. ${ }^{13 \mathrm{c}}$ Thus, 5-fluorouridine was first reacted with 2,2-dimethoxypropane and acetone in the presence of $p \mathrm{TsOH}$ to obtain the 2,3-isopropylidene-5fluorouridine, which was treated with succinic anhydride and 4-(dimethylamino)-pyridine (DMAP) in dichloromethane to provide $1 .{ }^{14}$ The partially protected sorbitol-based G8 molecular transporter (2) was prepared as previously reported, ${ }^{11 \mathrm{~b}}$ and coupled with the $N$-Cbz-protected $\omega$-aminohexanoic acid in dichloromethane in the presence of EDC and DMAP to give the molecular transporter with a Cbzamino functionality (3). The trityl group in $\mathbf{3}$ was selectively removed in the presence of several Boc groups to provide 4 by eluting with $\mathrm{CH}_{2} \mathrm{Cl}_{2} / \mathrm{MeOH}$ mixture through a flash $\mathrm{SiO}_{2}$ column packed in hexane containing 1\% TFA at the top and hexane containing $1 \% \mathrm{Et}_{3} \mathrm{~N}$ on the bottom. ${ }^{15}$ The hydroxyl group of 4 was coupled with the 5-fluorouridine derivative (1) in the presence of EDC and DMAP in DMF to give the conjugate (5) in moderate yield. The $N$-Cbz protecting group was removed by hydrogenolysis over $\mathrm{Pd} / \mathrm{C}$, and the product was treated with fluorescein-5-isothiocyanate (FITC-I) in the presence of triethylamine to yield 6. All $N$-Boc protecting groups in $\mathbf{6}$ were removed in ethyl acetate saturated with gaseous $\mathrm{HCl}$, followed by purification by RP-HPLC on a C18 column, to give the target conjugate (7) with a fluorophore (Scheme 1).

The unlabeled conjugate compound (9) was prepared in two steps from the intermediate compound (2). 5-Fluo-

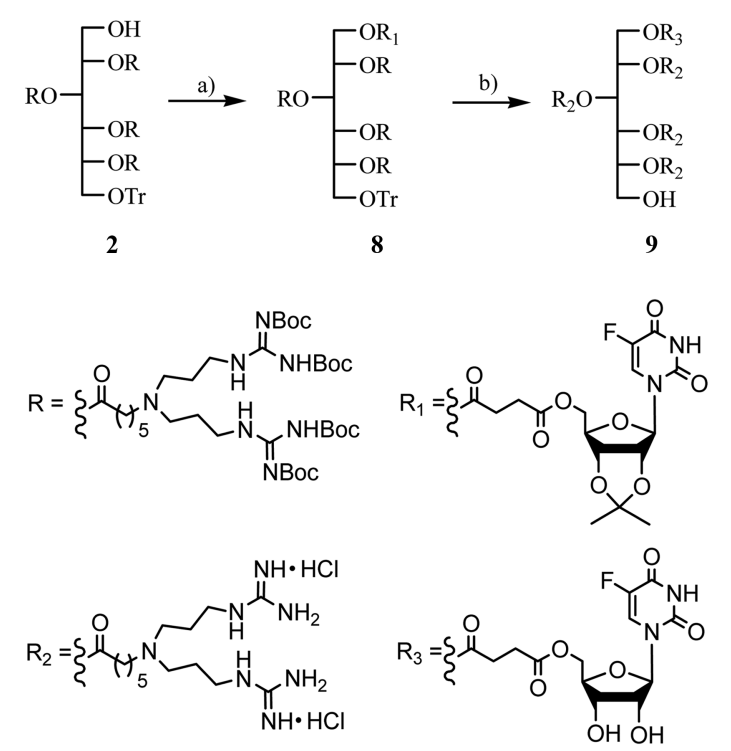

Scheme 2. (a) 1, EDC, DMAP, DMF, rt, 2 days, 80\%; (b) $\mathrm{HCl}$ (g) in EtOAc, rt, $24 \mathrm{hr}, 65 \%$. 
rouridine derivative (1) was coupled with the hydroxyl compound of $\mathbf{2}$ in the presence of EDC to give $\mathbf{8}$ in $80 \%$ yield after flash column chromatography. Removal of all protecting groups in compound $\mathbf{8}$ was performed by using ethyl acetate saturated with gaseous $\mathrm{HCl}$ at room temperature. The target compound (9) was obtained in $65 \%$ after purification by preperative RP-HPLC on a C18 column (Scheme 2). The target compounds and key synthetic intermediates were satisfactorily characterized by ${ }^{1} \mathrm{H}-,{ }^{13} \mathrm{C}-,{ }^{19} \mathrm{~F}-$ NMR and MALDI-TOF mass spectral analyses.

The uptake property of the conjugate (7) was examined by confocal microscopy (Olympus Fluoview FV1000, N.A. $1.30,40 \mathrm{X})$ in live HeLa cells. HeLa cells were incubated with compound $7(10 \mu \mathrm{M})$ at $37{ }^{\circ} \mathrm{C}$ for $30 \mathrm{~min}$. After extensive washing of the cells with PBS, the cellular uptake and localization of the compound were examined by the fluorescence of the labeled conjugate. As shown in Figure 2, the conjugate (7) displays efficient distribution in the cytosol. In order to investigate the intracellular localization further, we stained the cells with 7 and specific organelle markers. When HeLa cells were incubated with $7(10 \mu \mathrm{M})$ for $30 \mathrm{~min}$ and then with Mitotracker $(100 \mathrm{nM}$; a mitochondria marker, Invitrogen) for another $30 \mathrm{~min}$, a significant colocalization of the fluorescence signals in the merged image was observed and the intensity profiles have been recorded (Figure 2a). It is clear that the conjugate (7) targets mitochondria as the unloaded transporter itself does. ${ }^{11 \mathrm{~b}}$ This observation also suggests that as far as the mitochondrial affinity is concerned, the cargo (5-fluorouridine) effect is rather small. In contrast, when the cells were analogously incubated with 7 and Lysotracker (200 nM; a lysosome marker, Invitrogen) or rhodamine B-dextran conjugate (1 $\mathrm{mg} \mathrm{mL}^{-1}$; an early and late endosome marker, MW 10,000, Invitrogen), there were little or no colocalization detected (Figure $2 \mathrm{~b}$ and 2c). Since the intracellular localization studies do not show much fluorescence signal to indicate the endocytic process for the uptake, it may be suggested that both the sorbitol G8 transporter and its covalent conjugate of 5-fluorouridine (7) appear to employ an internalization mechanism that is substantially different from those suggested for common cell penetrating peptides (CPPs). ${ }^{16,17}$

The issue of the possible $\mathrm{BBB}$ penetration of the conjugate (a)



7

(b)

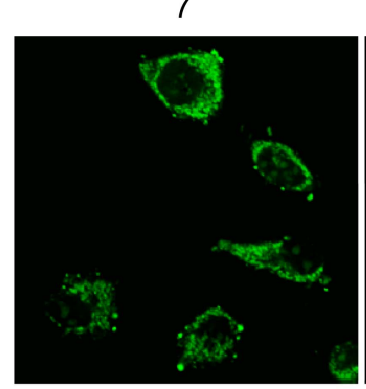

7

(c)

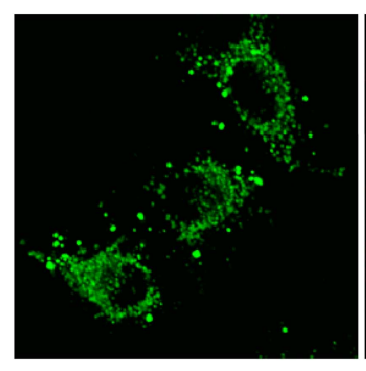

Mitotracker

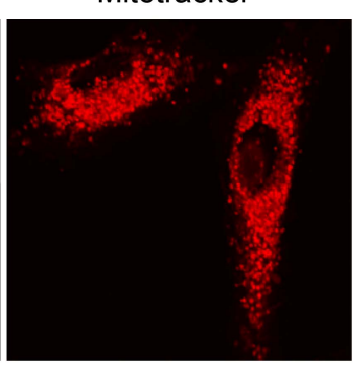

Lysotracker

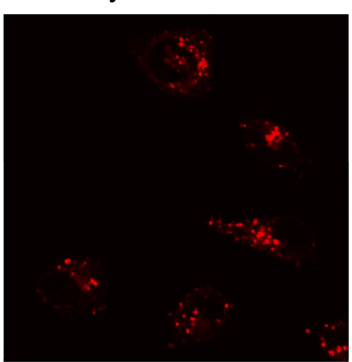

rhodamine B-dextran

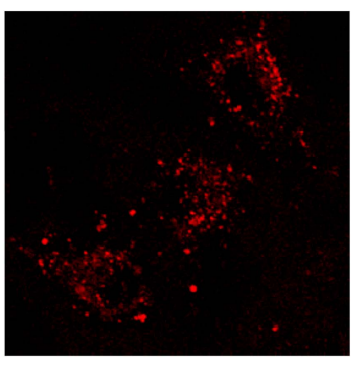

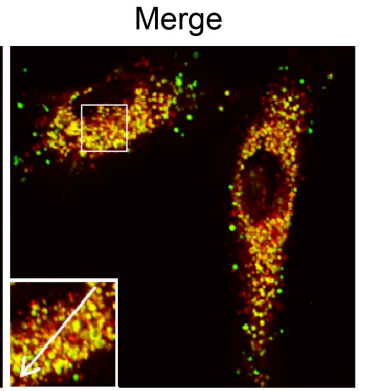

Merge

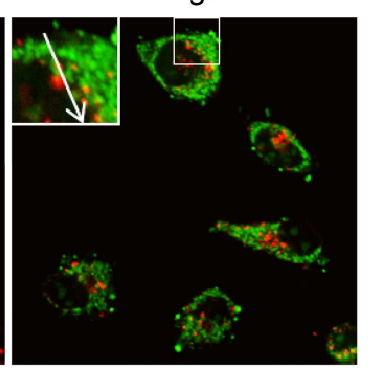

Merge

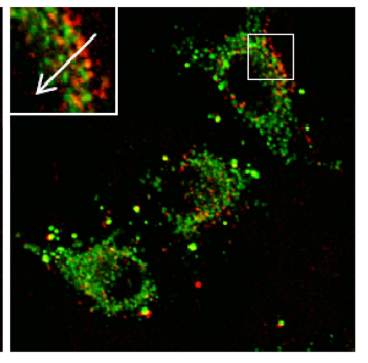

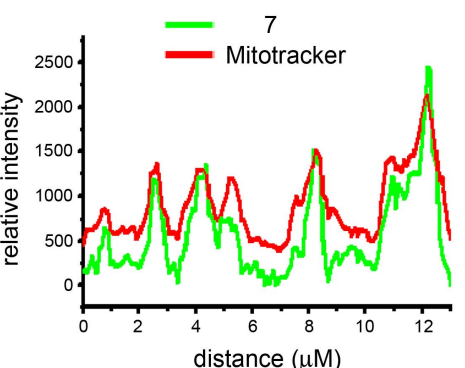
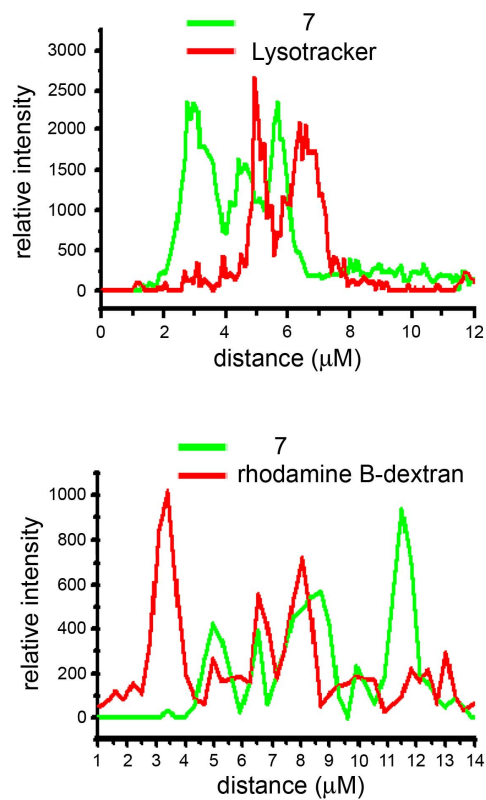

Figure 2. Confocal microscopy images of live HeLa cells. Compound 7 (green, $10 \mu \mathrm{M}, 1 \mathrm{hr}$ incubation) was coincubated with various subcellular markers (red). The intensity profiles of the fluorescence signals along the lines indicated in the insets of the merge images are shown on the right. (a) 7 and mitotracker $(100 \mathrm{nM}, 30 \mathrm{~min}$ incubation) as a mitochondria marker, (b) 7 and lysotracker (200 nM, $30 \mathrm{~min}$ incubation) as a lysosome marker, (c) 7 and rhodamine B-dextran conjugate (1 mg mL $\mathrm{m}^{-1}, 1 \mathrm{hr}$ incubation) as an early and late endosome marker. 


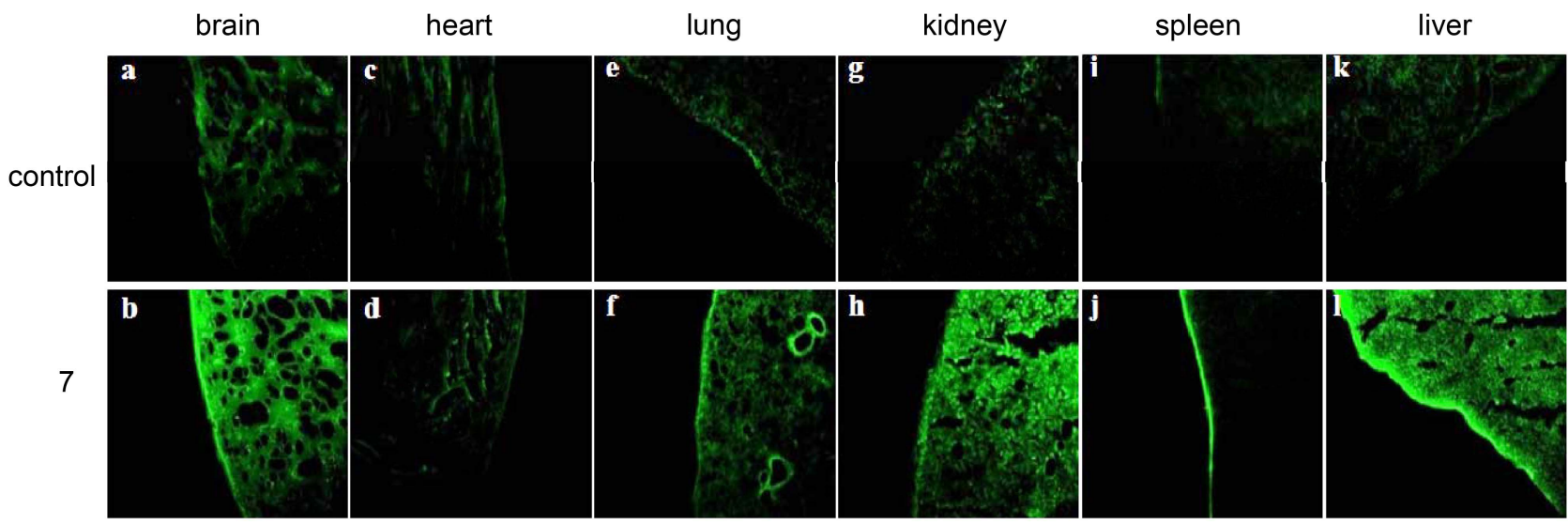

Figure 3. Tissue distribution patterns of compound (7) (bottom) against the control (top) in mouse. Fluorescence micrographs of: a \& b) brain, c) \& d) heart, e) \& f) lung, g) \& h) kidney, i) \& j) spleen, and k) \& l) liver tissue sections, isolated from mice 20 min after IP injection. Exposure times (ms): a) \& b) 5000, c) \& d) 1000 , e) \& f) 5000, g) \& h) 2000, i) \& j) 2000, and k) \& 1) $5000 . \lambda_{\max }=488 \mathrm{~nm}(\mathrm{green}$ fluorescence from FITC).

was next examined by studying the tissue distribution in mice. The conjugate (7) ( $\mathrm{HCl}$ salt, $94.4 \mathrm{mg} \mathrm{kg}^{-1}$ ) was dissolved in sterile distilled water and the solution was injected intraperitoneally (ip) into 8-week-old mice (C57BL/6). After $20 \mathrm{~min}$, the administered mice were perfused with paraformaldehyde $(4 \%)$ in phosphate buffered saline solution (PBS; pH 7.4), and the major organs such as brain, heart, lung, kidney, spleen, liver were incubated overnight in a
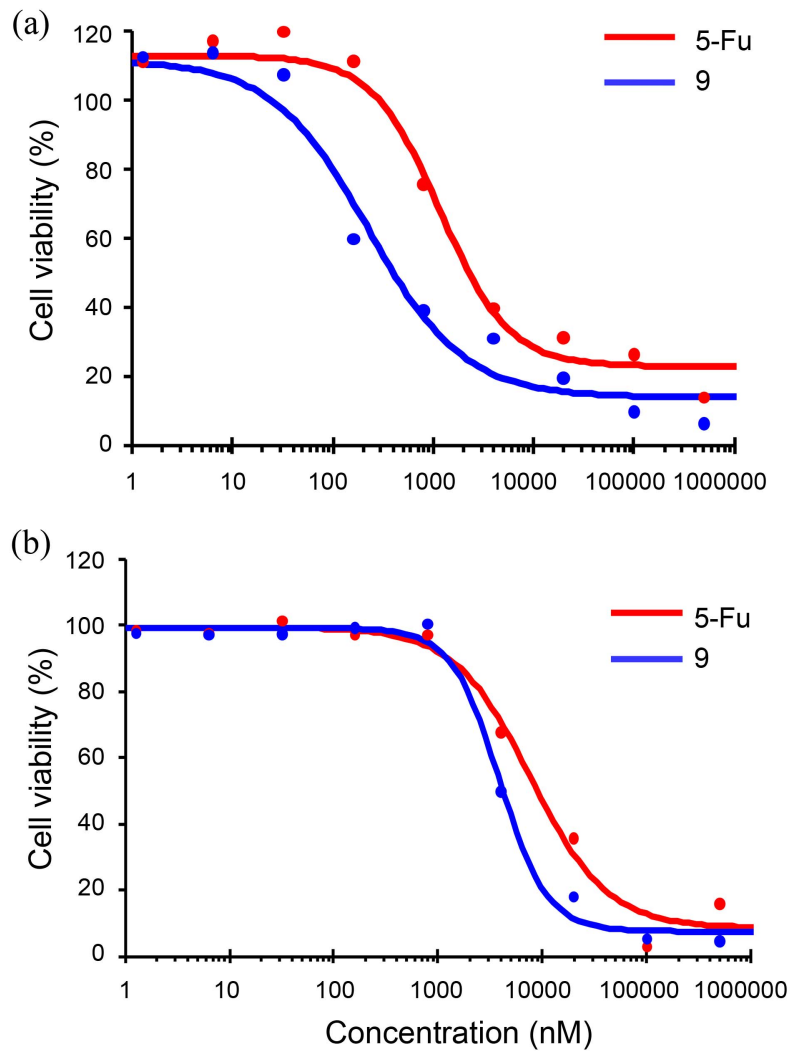

Figure 4. Cytotoxicity comparison of 9 and 5-FU toward multidrug-resistant cell lines. (a) DLD-1, (b) H1299. solution of sucrose $(0.5 \mathrm{M})$ in PBS. Placed in cryoprotectant, they were cut into $15-\mu \mathrm{m}$ sections with a cryostat and transferred to coated glass slides. After drying, each section was washed with PBS, treated with Triton X-100 (0.3\%) for $15 \mathrm{~min}$, and then analyzed with an Axioplan 2 fluorescence imaging microscope. The tissue distribution patterns of the sorbitol G8 transporters previously showed some preference to the heart and brain tissues than to other tissues examined such as liver, lung, spleen and kidney. ${ }^{11 \mathrm{~b}}$ Conjugate (7) exhibits a preference toward brain, kidney, liver and also to some extent lung. Much lesser distributions were observed to other organs such as heart and spleen (Figure 3).

The in vitro cytotoxicities of 5-FU and 9 were compared in two multidrug-resistant tumor cell lines: DLD-1 (human colon cancer cell, P-glycoprotein expression) and H1299 (human lung cancer cell, P-glycoprotein expression). Each cell line was treated with various concentrations of 5-FU and 9 respectively for $72 \mathrm{hrs}$, and then cell viabilities were determined by SRB colorimetric assay (Figure 4). ${ }^{18}$ Conjugate (9) was found to be somewhat more toxic than 5-FU. The enhanced cytotoxicity may be attributable to more efficient cellular uptake of conjugate (9) than the parent drug 5-FU.

\section{Conclusion}

5-Fluorouridine-sorbitol G8 transporter conjugates (7) with FITC and (9) without FITC were prepared. It has been demonstrated that 7 is efficiently taken up by HeLa cells, shows a good affinity toward mitochondria, and most significantly crosses BBB to gain an entry into mouse brain. Compared to 5-FU itself, conjugate (9) displays more potent in vitro cytotoxic activity toward two multidrug-resistant cell lines. Related studies are underway to demonstrate that these molecular transporters can be utilized in delivering other important drugs and drug candidates to brain and the central nervous system. 


\section{Experimental Section}

\section{Synthesis.}

General Methods: Column chromatography was performed on Merck 60 silica gel [70-230 or 230-400 mesh (flash)], and MPLC on Fluka 100 C8-reversed phase silica gel. All NMR spectra were recorded on a Bruker DPX 300 instrument operating at $300 \mathrm{MHz}$ for ${ }^{1} \mathrm{H}, 75 \mathrm{MHz}$ for ${ }^{13} \mathrm{C}$ and $282 \mathrm{MHz}$ for ${ }^{19} \mathrm{~F}$, unless otherwise stated. The chemical shifts are reported in $\delta$ ppm with TMS as reference standard. MALDI-TOF-MS was obtained on a Micromass M@DI at the Biomolecular Diversity Core Facility (POSTECH). Melting points were determined on a Thomas-Hoover MP apparatus and are uncorrected. Analytical HPLC was performed on Agilent 1100-HPLC Chemstation with an analytical column ZORBAX SB-C8 (5 $\mu \mathrm{m}, 100 \AA$, $4.6 \times$ $250 \mathrm{~mm})$.

5'-Succinyl-2',3'-isopropylidene-5-fluorouridine (1): A mixture of 2',3'-isopropylidene-5-fluorouridine (50 mg, 0.16 mmol) and 4-dimethylaminopyridine (DMAP) (24 mg, 0.19 mmol) was suspended in $5 \mathrm{~mL}$ of anhydrous dichloromethane. Succinic anhydride $(20 \mathrm{mg}, 0.19 \mathrm{mmol})$ was added to the mixture, and after stirring for $18 \mathrm{hr}$, the solvent was evaporated and the residue was directly purified by flash column chromatography to give $1(55 \mathrm{mg}, 83 \%)$ as white solid. $R_{f}: 0.4\left(\mathrm{CH}_{2} \mathrm{Cl}_{2}: \mathrm{MeOH}=1: 10\right) ; \mathrm{mp} 133-136{ }^{\circ} \mathrm{C}$ [lit. ${ }^{14}$ mp 135-140 ${ }^{\circ} \mathrm{C}$ ); ${ }^{1} \mathrm{H}$ NMR (in DMSO- $d_{6}, \delta$ ) $1.34(\mathrm{~s}, 3 \mathrm{H})$, $1.53(\mathrm{~s}, 3 \mathrm{H}), 2.65(\mathrm{~m}, 4 \mathrm{H}), 4.88-4.90(\mathrm{~m}, 1 \mathrm{H})$, 5.07-5.09 (m, 1H), $5.87(\mathrm{~m}, 1 \mathrm{H}), 7.90(\mathrm{~d}, J=6.5 \mathrm{~Hz}, 1 \mathrm{H}) ;{ }^{13} \mathrm{C} \mathrm{NMR}$ (in $\mathrm{MeOD}, \delta)$ 25.4, 27.3, 29.4, 29.6, 64.6, 81.5, 85.0, 85.3, 93.4, 114.7, 126.7, 140.4, 142.3, 149.8, 157.5, 172.7; ${ }^{19} \mathrm{~F}$ NMR (in MeOD, $\delta$ ) -92.31; HR-FABMS [M+H] $]^{+}$calcd for $\mathrm{C}_{16} \mathrm{H}_{20} \mathrm{FN}_{2} \mathrm{O}_{9} m / z$ 403.1153, found 403.1148.

1-O-Trityl-2,3,4,5-tetra- $O$ - $\left(N\right.$ - $\left\{\right.$ bis- $\left[3-\left(N^{\prime}, N^{\prime \prime}\right.\right.$-bis-Bocguanidino)-propyl]\}-6-aminohexanoyl)-D-sorbitol (2) was prepared according to a literature procedure. ${ }^{11 \mathrm{~b}}$

1-O-(N-Cbz-6-aminohexanoyl)-2,3,4,5-tetra- $\mathrm{O}-(\mathrm{N}$ - $\{$ bis[3-( $N^{\prime}, N^{\prime \prime}$-bis-Boc-guanidino)-propyl]\}-6-aminohexanoyl)6-O-trityl-D-sorbitol (3) was prepared according to a literature procedure. ${ }^{11 \mathrm{~b}}$

1-O-( $\mathrm{N}$-Cbz-6-aminohexanoyl)-2,3,4,5-tetra- $\mathrm{O}-(\mathrm{N}$ - $\{$ bis[3-( $N^{\prime}, N^{\prime \prime}$-bis-Boc-guanidino)-propyl]\}-6-aminohexanoyl)D-sorbitol (4): A column of flash silica gel was packed consecutively with $1 \%$ TEA in hexane and then with $1 \%$ TFA in hexane. A layer of sea sand was placed in-between. Compound 3 (98 mg, $0.0278 \mathrm{mmol}$ ) was dissolved in 1\% TFA-containing dichloromethane and sonicated for a few seconds. The solution was then loaded onto the column, and the column was eluted with dichloromethane/ $\mathrm{MeOH}$ to give compound 4 (66 mg, 73\%). $R_{f}: 0.44\left(\mathrm{CH}_{2} \mathrm{Cl}_{2}: \mathrm{MeOH}=\right.$ 10:1); ${ }^{1} \mathrm{H}$ NMR (in $\mathrm{CDCl}_{3}, \delta$ ) 1.22-1.79 (m, 190H), 2.02$2.62(\mathrm{~m}, 32 \mathrm{H}), 3.15-3.48(\mathrm{~m}, 18 \mathrm{H}), 3.68(\mathrm{~m}, 2 \mathrm{H}), 4.31-4.40$ (m, 4H), 4.89-5.07 (m, 2H), $5.08(\mathrm{~s}, 2 \mathrm{H}), 5.10-5.30(\mathrm{~m}, 2 \mathrm{H})$, 7.34 (m, 5H), 8.51 (brs, 8H), 11.48 (brs, 8H); ${ }^{13} \mathrm{C}$ NMR (in $\left.\mathrm{CDCl}_{3}, \delta\right) 14.12,22.68,23.99,24.33,24.76,25.27,26.34$, $27.10,28.03,28.06,28.29,28.31,28.81,29.35,29.69$, 29.93, 33.94, 35.49, 37.96, 39.03, 40.86, 49.91, 51.31,
$51.47,51.51,53.14,63.63,66.48,79.18,79.73,79.96$, $80.51,82.98,83.28,83.66,84.54,84.89,85.06,93.41$, $114.50,118.32,122.61,127.20,127.87,128.03,128.48$, $128.69,136.73,142.11,143.27,148.75,153.02,153.09$, $155.84,156.14,156.74,163.55,171.76,172.55,172.73$, $172.78,173.07,181.58,185.05,185.17$.

1-O-(2',3'-Isopropylidene-5-fluorouridine-5'-succinoyl)2,3,4,5-tetra- $O$-( $N$-\{bis-[3-( $N^{\prime}, N^{\prime \prime}$-bis-Boc-guanidino)-propyl]\}-6-aminohexanoyl)-6-O-( $\mathrm{N}$-Cbz-6-aminohexanoyl)-Dsorbitol (5): A solution of 4 (82 mg, $0.025 \mathrm{mmol}), \mathbf{1}(15 \mathrm{mg}$, $0.037 \mathrm{mmol}$ ), EDC (10 mg, $0.049 \mathrm{mmol})$ and DMAP (2 mg) in DMF (4 mL) was stirred at $\mathrm{rt}$ for $48 \mathrm{hr}$ under $\mathrm{N}_{2}(\mathrm{~g})$. The solution was diluted with EtOAc, and washed several times with saturated aq. $\mathrm{NaHCO}_{3}$, water and brine. The organic phase was dried and concentrated to give the crude product, which was purified by column chromatography on silica gel to afford 5 (65 mg, 71\%) as white foamy solid. $R_{f}: 0.45$ $\left(\mathrm{CH}_{2} \mathrm{Cl}_{2}: \mathrm{MeOH}=10: 1\right)$; ${ }^{1} \mathrm{H}$ NMR (in $\left.\mathrm{CDCl}_{3}, \delta\right)$ 1.27-1.68 (m, 203H), 2.28-2.72 (m, 32H), 3.15-3.50 (m, 18H), 3.66 (m, 2H), 4.31-4.40 (m, 4H), $4.83(\mathrm{~m}, 2 \mathrm{H}), 5.08(\mathrm{~s}, 2 \mathrm{H}), 5.35$ (m, 4H), $5.75(\mathrm{~s}, 1 \mathrm{H}), 7.20-7.38(\mathrm{~m}, 5 \mathrm{H}), 7.57(\mathrm{~m}, 1 \mathrm{H}), 8.49-$ 8.57 (brs, 8H), 11.44 (brs, 8H); ${ }^{13} \mathrm{C} \mathrm{NMR} \mathrm{(in} \mathrm{CDCl}_{3}, \delta$ ) $14.12,22.68,23.99,24.33,24.76,25.27,26.34,27.10$, $28.03,28.06,28.29,28.31,28.81,29.35,29.69,29.93$, $33.94,35.49,37.96,39.03,40.86,49.91,51.31,51.47$, $51.51,53.14,63.63,66.48,79.18,79.73,79.96,80.51$, $82.98,83.28,83.66,84.54,84.89,85.06,93.41,114.50$, $118.32,122.61,127.20,127.87,128.03,128.48,128.69$, $136.73,142.11,143.27,148.75,153.02,153.09,155.84$, $156.14,156.74,163.55,171.76,172.55,172.73,172.78$, 173.07, 181.58, 185.05, 185.17; ${ }^{19} \mathrm{~F} \mathrm{NMR} \mathrm{(in} \mathrm{CDCl}_{3}, \delta$ ) -89.10 .

1-O-(2',3'-Isopropylidene-5-fluorouridine-5'-succinoyl)2,3,4,5-tetra- $O$-[ $N$-\{bis-(3-( $N^{\prime}, N^{\prime \prime}$-bis-Boc-guanidino)-propyl]\}-6-aminohexanoyl]-6-O-[6-(fluoresceinyl-5-thioureido)hexanoyl]-D-sorbitol (6): A solution of 5 (35 mg, 0.0096 mmol) in a mixed solvent $\left(\mathrm{CH}_{2} \mathrm{Cl}_{2}: \mathrm{MeOH}=1: 9,10 \mathrm{~mL}\right)$ was hydrogenated (50 psi) over $10 \% \mathrm{Pd} / \mathrm{C}(10 \mathrm{mg})$ at $\mathrm{rt}$. After $12 \mathrm{hr}$, the catalyst was filtered and the filtrate was evaporated to give the amino compound ( $33.5 \mathrm{mg}$, quant.) as an off-white foamy solid. ${ }^{1} \mathrm{H}$ NMR (in $\mathrm{CDCl}_{3}$ ) 1.28-1.82 (m, $203 \mathrm{H}), 2.32-2.66(\mathrm{~m}, 32 \mathrm{H}), 3.05-3.48(\mathrm{~m}, 18 \mathrm{H}), 3.66(\mathrm{~m}$, $2 \mathrm{H}), 4.30-4.38(\mathrm{~m}, 4 \mathrm{H}), 4.80-5.07(\mathrm{~m}, 2 \mathrm{H}), 5.07(\mathrm{~m}, 2 \mathrm{H})$, $5.36(\mathrm{~m}, 2 \mathrm{H}), 5.76(\mathrm{~s}, 1 \mathrm{H}), 7.56(\mathrm{~m}, 1 \mathrm{H}), 8.50-8.55$ (brs, $8 \mathrm{H}), 11.40$ (brs, 8H).

To a solution of the amino compound obtained above (27 mg, $0.008 \mathrm{mmol}$ ) in a mixed solvent of THF and abs. ethanol $(2: 4,3 \mathrm{~mL})$, were added fluorescein-5-isothiocyanate $(4.5 \mathrm{mg}, 0.011 \mathrm{mmol})$ and triethylamine $(3 \mu \mathrm{L}$, $0.024 \mathrm{mmol}$ ). The reaction mixture was stirred for $36 \mathrm{hr}$ at $\mathrm{rt}$ in dark and concentrated. The crude product was purified on silica gel to afford $6(17 \mathrm{mg}, 57 \%)$ as a light greenish-yellow sticky solid. $R_{f}: 0.40\left(\mathrm{CH}_{2} \mathrm{Cl}_{2}: \mathrm{MeOH}=10: 1\right) ;{ }^{1} \mathrm{H} \mathrm{NMR}$ (in $\left.\mathrm{CDCl}_{3}, \delta\right)$ 1.28-1.82 (m, 203H), 2.32-2.66 (m, 32H), 2.98$3.48(\mathrm{~m}, 18 \mathrm{H}), 3.66(\mathrm{~m}, 2 \mathrm{H}), 4.11-4.37(\mathrm{~m}, 4 \mathrm{H}), 4.80-5.07$ (m, 4H), 5.31-5.84 (m, 2H), $5.76(\mathrm{~s}, 1 \mathrm{H}), 6.59-6.94(\mathrm{~m}, 4 \mathrm{H})$, 7.24-7.36 (m, 4H), $7.72(\mathrm{~m}, 1 \mathrm{H}), 8.05(\mathrm{~m}, 1 \mathrm{H}), 8.51-8.55$ 
(brs, 8H), 11.40 (brs, 8H); ${ }^{13} \mathrm{C} \mathrm{NMR} \mathrm{(in} \mathrm{CDCl}_{3}, \delta$ ) 14.12, $22.69,24.24,24.83,25.24,25.61,26.42,27.11,28.03$, $28.06,28.29,29.36,29.53,29.70,29.96,31.92,34.01$, $35.49,38.08,39.37,45.90,50.01,51.46,53.14,58.38$, $63.85,67.96,79.23,79.79,82.99,83.27,83.66,84.54$, $84.74,103.38,114.52,118.34,122.63,127.22,127.89$, $128.69,128.79,129.70,129.92,140.89,143.28,148.81$, $153.01,153.11,155.83,156.17,156.75,162.88,171.17$, $172.01,172.78,173.03,173.21,174.10181 .73,185.16 ;{ }^{19} \mathrm{~F}$ $\mathrm{NMR}$ (in $\left.\mathrm{CDCl}_{3}, \delta\right)-89.99$.

1-O-(5-Fluorouridine-5'-succinoyl)-2,3,4,5-tetra- $O$-[ $N$ - $\{$ bis(3-guanidinopropyl)\}-6-aminohexanoyl]-6-O-[6-(fluoresceinyl-5-thioureido)-hexanoyl]-D-sorbitol-8HCl (7): To a solution of $6(17 \mathrm{mg}, 0.004 \mathrm{mmol})$ in EtOAc $(1 \mathrm{~mL})$ at $\mathrm{rt}$, was added $\mathrm{HCl}(\mathrm{g})$ saturated solution of EtOAc $(5 \mathrm{~mL})$. After stirring for $24 \mathrm{hr}$, the solution was concentrated, and the residue was washed with a mixture of diethyl ether and $\mathrm{MeOH}(20: 1)$ to remove less polar impurities. The residue was dried and purified by MPLC on reverse phase $\mathrm{C} 8$ silica gel $\left(\mathrm{H}_{2} \mathrm{O} / \mathrm{CH}_{3} \mathrm{CN}=1: 1\right.$ to $1: 2$ with $0.1 \%$ TFA $)$. The purified product was dissolved in deionized water, filtered through polytetrafluoroethylene (PTFE) syringe filter, and lyophilized to give $7(8.0 \mathrm{mg}, 72 \%)$ as light greenish-yellow foamy solid. UV $\left(\mathrm{H}_{2} \mathrm{O}\right) \lambda_{\max }=486 \mathrm{~nm}, \varepsilon=17488 \mathrm{~cm}^{-1} \mathrm{M}^{-1} ;{ }^{1} \mathrm{H}$ NMR (MeOD) 1.22-1.79 (m, 40H), 2.05-2.16 (m, 16H), 2.35-2.97 (m, 16H), 3.29-3.60 (m, 16H, partially overlapping with $\left.\mathrm{CD}_{3} \mathrm{OD}\right), 3.48-3.65(\mathrm{~m}, 6 \mathrm{H}), 4.10-4.54(\mathrm{~m}, 9 \mathrm{H})$, 5.23-5.33 (m, 2H), $5.84(\mathrm{~m}, 1 \mathrm{H}), 6.66-6.82(\mathrm{~m}, 4 \mathrm{H}), 7.21-$ $7.32(\mathrm{~m}, 3 \mathrm{H}), 7.70(\mathrm{~m}, 1 \mathrm{H}), 7.88-7.90(\mathrm{~m}, 1 \mathrm{H}), 8.05(\mathrm{~m}$, $1 \mathrm{H}$ ); ${ }^{19} \mathrm{~F}$ NMR (in MeOD, $\delta$ ) -88.91; MALDI-TOF-MS $[\mathrm{M}+\mathrm{Na}]^{+}$calcd for $\mathrm{C}_{102} \mathrm{H}_{166} \mathrm{FN}_{32} \mathrm{O}_{24} \mathrm{SNa} m / z$ 2298.66, found 2298.98; analytical HPLC (ZORBAX SB-C8, $220 \mathrm{~nm}$, flow rate: $1 \mathrm{~mL} \mathrm{~min}{ }^{-1}, \mathrm{CH}_{3} \mathrm{CN}: \mathrm{H}_{2} \mathrm{O}=40: 60, t_{\mathrm{R}}=2.39 \mathrm{~min}$ ), purity $94+\%$.

1-O-(2',3'-Isopropylidene-5-fluorouridine-5'-succinoyl)2,3,4,5-tetra- $O$-[ $N$ - $\left\{\right.$ bis-(3-( $N^{\prime}, N^{\prime \prime}$-bis-Boc-guanidino)-propyl]\}-6-aminohexanoyl]-6-O-trityl-D-sorbitol (8): A solution of 2 (184 mg, $0.056 \mathrm{mmol}$ ), 1 (34 mg, $0.084 \mathrm{mmol}$ ), EDC (16 mg, $0.084 \mathrm{mmol})$ and DMAP (2 mg) in DMF (4 $\mathrm{mL}$ ) was stirred at $\mathrm{rt}$ for $48 \mathrm{hr}$ under $\mathrm{N}_{2}(\mathrm{~g})$. The reaction mixture was diluted with EtOAc, and washed several times with saturated aq. $\mathrm{NaHCO}_{3}$, water and brine. The organic phase was dried over $\mathrm{Na}_{2} \mathrm{SO}_{4}$, filtered, and concentrated to give the crude product, which was purified by column chromatography on silica gel to afford $8(162 \mathrm{mg}, 80 \%)$ as white foamy solid. $R_{f}: 0.45\left(\mathrm{CH}_{2} \mathrm{Cl}_{2}: \mathrm{MeOH}=10: 1\right) ;{ }^{1} \mathrm{H}$ NMR (in $\mathrm{CDCl}_{3}, 500 \mathrm{MHz}, \delta$ ) 1.09-1.70 (m, 193H), 2.03$2.04(\mathrm{~m}, 3 \mathrm{H}), 2.28-2.26(\mathrm{~m}, 30 \mathrm{H}), 2.95-3.50(\mathrm{~m}, 16 \mathrm{H}), 3.66$ $(\mathrm{m}, 4 \mathrm{H}), 4.28-4.37(\mathrm{~m}, 4 \mathrm{H}), 4.83-4.85(\mathrm{~m}, 3 \mathrm{H}), 5.32-5.68$ $(\mathrm{m}, 2 \mathrm{H}), 5.69(\mathrm{~s}, 1 \mathrm{H}), 7.22-7.38(\mathrm{~m}, 15 \mathrm{H}), 7.49-7.51(\mathrm{~m}$, 1H), 8.51-8.56 (brs, 8H), 11.49 (brs, 8H); ${ }^{13} \mathrm{C}$ NMR (in $\left.\mathrm{CDCl}_{3}, 125 \mathrm{MHz}, \delta\right)$ 13.50, 20.02, 22.58, 24.53, 25.05, $25.20,25.83,27.02,27.97,29.25,29.59,31.82,33.72$, $36.38,38.39,39.00,39.32,50.37,51.29,51.95,53.35$, $53.58,63.65,69.42,69.63,70.47,79.05,79.41,82.84$, $83.31,84.42,114.27,118.26,122.54,126.82,127.11$, $127.76,127.88,128.44,128.58,142.04,143.28,143.37$,
$152.99,156.03,156.43,162.46,163.05,163.48,171.59$, $171.74,172.25,172.44,172.75,172.91,181.71 ;{ }^{19} \mathrm{~F}$ NMR (in $\left.\mathrm{CDCl}_{3}, \delta\right)-88.93$.

1-O-(5-Fluorouridine-5'-succinoyl)-2,3,4,5-tetra- $O$ - $[N$ - $\{$ bis(3-guanidinopropyl)\}-6-aminohexanoyl]-D-sorbitol-8HCl (9): Compound 8 (29 mg, $7.9 \mathrm{~mol})$ was added to a solution of EtOAc saturated with gaseous $\mathrm{HCl}(3 \mathrm{~mL})$ at $\mathrm{rt}$, and the solution was stirred for 2 days. After evaporation, diethyl ether was added and decanted several times. The precipitate was dissolved in deionized water, filtered through a PTFE syringe filter, and lyophilized to give the crude product, which was purified by using preparative RP-HPLC


$\left.\mathrm{H}_{2} \mathrm{O}, 260 \mathrm{~nm}\right)$ to yield $9(15 \mathrm{mg}, 90 \%)$ as white sticky solid. ${ }^{1} \mathrm{H}$ NMR (in $\left.\mathrm{D}_{2} \mathrm{O}, 500 \mathrm{MHz}, \delta\right)$ 1.10-1.45 (m, 6H), 1.53-1.92 $(\mathrm{m}, 10 \mathrm{H}), 1.99-2.22(\mathrm{~m}, 12 \mathrm{H}), 2.30-2.49(\mathrm{~m}, 5 \mathrm{H}), 2.66-2.90$ $(\mathrm{m}, 9 \mathrm{H}), 3.05-3.49(\mathrm{~m}, 25 \mathrm{H}), 3.60-4.01(\mathrm{~m}, 4 \mathrm{H}), 4.10-4.70$ (m, 14H), 4.88-5.55 (m, 3H), 5.85 (brs, 1H), 7.95 (brs, 1H); ${ }^{13} \mathrm{C}$ NMR (in $\mathrm{D}_{2} \mathrm{O}, 125 \mathrm{MHz}, \delta$ ) 23.17, 23.97, 25.44, 25.53, $29.90,30.04,30.20,33.57,38.48,50.55,52.44,53.12$, $63.75,69.35,74.09,81.46,84.48,87.75,90.29,125.58$, $157.14,174.26 ;{ }^{19} \mathrm{~F}$ NMR (in $\mathrm{D}_{2} \mathrm{O}, \delta$ ) -89.60; MALDI-TOF$\mathrm{MS}[\mathrm{M}+\mathrm{H}]^{+}$calcd for $\mathrm{C}_{75} \mathrm{H}_{144} \mathrm{FN}_{30} \mathrm{O}_{18} \mathrm{~m} / z$ 1772.1251, found 1772.0652; analytical HPLC (GRACEVYDAC-C18, 220

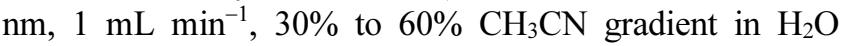
during $25 \mathrm{~min}, t_{\mathrm{R}}=3.69 \mathrm{~min}$ ), purity $99+\%$.

\section{Bioassays}

Cell Culture. HeLa cells were cultured at $37^{\circ} \mathrm{C}$ in a humidified 5\% $\mathrm{CO}_{2}$ containing air environment in Dulbecco's modified Eagle's medium (DMEM, Invitrogen) and 10\% (v/v) fetal bovine serum (FBS, Sigma) with antibiotics. The subculture was conducted every 2-3 days using the cells grown to subconfluence.

Uptake Experiments. For each assay, HeLa cells were seeded into a 35-mm glass bottomed dish (SPL, Korea) and cultured for $24 \mathrm{hrs}$. After removing the medium, HeLa cells were washed with PBS (X1). The cells were incubated for $30 \mathrm{~min}$ at $37{ }^{\circ} \mathrm{C}$ in $2 \mathrm{~mL}$ of DMEM containing $10 \mu \mathrm{M}$ of 7 . For subcellular staining, HeLa cells were pretreated with 7 as described and then $100 \mathrm{nM}$ Mitotracker or $200 \mathrm{nM}$ Lysotracker was added and incubated for further $30 \mathrm{~min}$. 1 $\mathrm{mg} \mathrm{mL} \mathrm{m}^{-1}$ rhodamine B-dextran conjugates were incubated together with 7 for $1 \mathrm{hr}$.

Confocal Laser Scanning Microscopy (CLSM). Each dish of HeLa cells was washed five times with cold PBS, and then CLSM was performed by using an Olympus Fluoview FV1000 (N.A. 1.30, 40X) without fixing the cells. Fluorescence was analyzed and collected using the following excitation and emission bands: FITC, $488 \mathrm{~nm}$ (ex), 520$550 \mathrm{~nm}$ (em); Mitotracker, Lysotracker, and rhodamine Bdextran, $543 \mathrm{~nm}$ (ex), 600-700 nm (em). Merged images and intensity profiles were obtained by the Olympus Fluoview Viewer.

Protocols for the Tissue Biodistribution Study were previously described. ${ }^{11 \mathrm{f}}$ 
Acknowledgments. This work is financially supported by the BK-21 Program and the National Frontier Research Program administered through KRICT/CBM (MOEST of Korean government).

\section{References}

1. (a) Wilson and Gisvold's Textbook of Organic Medicinal and Pharmaceutical Chemistry, 11th ed.; Block, J. H.; Beal, J. M., Jr.; Lippincott Williams \& Wilkins: 2004; pp 402-414. (b) Mader, M. M.; Henry, J. R. In Comprehensive Medicinal Chemistry II; vol. 7, Plattner, J. J., Desai, M. C., Eds.; Elsevier: Oxford, U. K. 2007; pp 55-80.

2. Longley, D. B.; Harkin, P.; Johnson, P. G. Nature Reviews Cancer 2003, 3, 330 .

3. (a) Santi, D. V.; McHenry, C. S. Proc. Nat. Acad. Sci. USA 1972, 69, 1855. (b) Zhang, N.; Yin, Y.; Xu, S. J.; Chen, W. S. Molecules 2008, 13, 1551. (c) Purser, S.; Moore, P. R.; Swallow, S.; Gouverneur, V. Chem. Soc. Rev. 2008, 37, 320.

4. (a) Moore, M. J.; Erlichman, C. Pharmacology of Anticancer Drugs in The Basic Science of Oncology, 3rd ed.; Tannock, I. F., Hill, R. F., Eds.; McGraw-Hill: NY, 1998; pp 370-391. (b) de Gramont, A.; Louvet, C.; Andre, T.; Tournigand, C.; Krulik, M. Eur. J. Cancer 1998, 34, 619.

5. (a) Shimma, N.; Umeda, I.; Arasaki, M.; Murasaki, C.; Masubuchi, K.; Kohchi, Y.; Miwa, M.; Ura, M.; Sawada, N.; Tahara, H.; Kuruma, I.; Horii, I.; Ishitsuka, H. Bioorg. Med. Chem. 2000, 8, 1697. (b) Koukourakis, G. V.; Kouloulias, V.; Koukourakis, M. J.; Zacharias, G. A.; Zabatis, H.; Kouvaris, J. Molecules 2008, 13, 1897.

6. (a) Ishikawa, T.; Utoh, M.; Sawada, N.; Nishda, M.; Fukase, Y.; Sekiguch, F.; Ishitsuka, H. Biochem. Pharmacol. 1998, 55, 1091. (b) Walko, C. M.; Lindley, C. Clin. Ther. 2005, 27, 23. (c) Testa, B. Biochem. Pharmacol. 2004, 68, 2097.

7. Formica, V.; Leary, A.; Cunningham, D.; Chua, Y. J. Cancer Chemother. Pharmacol. 2006, 58, 276.
8. (a) Lesniak, M. S.; Brem, H. Nat. Rev. Drug Discovery 2004, 3 , 499. (b) Pardridge, W. M. Drug Discovery Today 2007, 12, 54.

9. (a) Benoit, J. P.; Faisant, N.; Venier-Julienne, M. C. Menei, P. J. Control. Release 2000, 65, 1079. (b) Menei, P.; Jadaud, E.; Faisant, N.; Boisdron-Celle, M.; Michalak, S.; Fournier, D.; Delhaye, M.; Benoit, J. P. Cancer 2004, 100, 405.

10. Soni, V.; Kohli, D. V.; Jain, S. K. J. Drug Targeting 2008, 16, 73.

11. (a) Maiti, K. K.; Jeon, O. Y.; Lee, W. S.; Kim, D. C.; Kim, K. T; Takeuchi, T.; Futaki, S.; Chung, S. K. Angew. Chem. Int. Ed. 2006, 56, 2907. (b) Maiti, K. K.; Lee, W. S.; Takeuchi, T.; Watkins, C.; Fretz, M.; Kim, D. C.; Futaki, S.; Jones, A.; Kim, K-T.; Chung, S. K. Angew. Chem. Int. Ed. 2007, 46, 5880. (c) Biswas, G.; Jeon, O. Y.; Lee, W. S.; Kim, D. C.; Kim, K. T.; Lee, S.; Chang, S.; Chung, S. K. Chem. Eur. J. 2008, 14, 9161. (d) Chung, S. K.; Maiti, K. K.; Lee, W. S. Int. J. Pharm. 2008, 354, 16. (e) Im, J.; Kim, W.; Kim, K. T.; Chung, S. K. Chem. Commun. 2009, 4649. (f) Ghosh, S. C.; Kim, B.; Im, J.; Lee, W. S.; Im, C. N.; Chang, Y. T.; Kim, W.; Kim, K. T.; Chung, S. K. Bull. Korean Chem. Soc. 2010, 31, 3623.

12. Jin, J.; Lee, W. S.; Joo, K. M.; Maiti, K. K.; Biswas, G.; Kim, W.; Kim, K. T.; Lee, S. J.; Kim, K. H.; Nam, D. H.; Chung, S. K. Med. Chem. Commun. 2011, DOI: 10.1039/c0md00235f.

13. (a) Testa, B. In Comprehensive Medicinal Chemistry II; vol 5., Testa, B., van de Waterbeemd, H., Eds.; Elsevier: Amsterdam, 2007, pp 1009-1041. (b) Rautio, J.; Laine, K.; Gynther, M.; Savolainen, J. AAPS J. 2008, 10, 92. (c) Gomes, P.; Vale, N.; Moreira, R. Molecules 2007, 12, 2484.

14. Crosasso, P.; Brusa, P.; Dosio, F.; Arpicco, S.; Pacchioni, S.; Schuber, F.; Cattel, L. J. Pharm. Sci. 1997, 86, 832.

15. Pathak, A. K.; Pathak, V.; Seitz, L. E.; Tiwari, K. N.; Akhtar, M. S.; Reynolds, R. C. Tetrahedron Lett. 2001, 42, 7755.

16. Nakase, I.; Takeuchi, T.; Tanaka, G.; Futaki, S. Adv. Drug Del. Rev. 2008, 60, 598.

17. Wender, P. A.; Galliher, W. C.; Goun, E. A.; Jones, L. R.; Pillow, T. H. Adv. Drug Deliv. Rev. 2008, 60, 452.

18. We thank Dr. Sun-Ok Kim of Samyang Central R\&D Center for carrying out these measurements. 